\title{
METHODOLOGICAL BASIS OF THE RESEARCH OF LEGAL ALGORITHMS
}

Manko D. G.

\section{INTRODUCTION}

Disclosure of the essence and legal nature of legal algorithms, and technologies of legal activity is connected with the necessity of establishing clear methodological tools, defining terms, concepts and categories of application of which will ensure the completeness, and comprehensiveness of their scientific comprehension.

Correct methodological planning of the principals of the research is the key to a consistent study of the problem identified, the achievement of the goal and the fullest disclosure of the tasks set.

P.M. Rabinovich, defines the methodology of legal science (in the narrow sense) as "a system of approaches, methods and approach of scientific research, a theoretical basis for their use in the study of state and legal phenomena" 1 .

In her turn, N. Onishchenko, analyzing the methodology of the theory of state and law, noted that the latter, being a systematic set of special cognitive methods, means, methods of studying the state and law, laws of their origin and development, is based on certain, inherent principles of research state and legal reality ${ }^{2}$.

S.S. Slivka indicates, that "under methodology should be understood to have acquired settings, formed views, a certain point of view and, in general, and a worldview that can be implemented using certain methods, approaches and means"3.

Particular attention should be paid to the definition methodology of state theory and law, formulated by O.F. Skakun: "it is a system of general approaches, principles, methods, and means of knowing the law and the state, realized on the basis of knowledge about the laws of their application,

${ }^{1}$ Рабінович П. М. Методологія юридичної науки // Юридична енциклопедія. К., 2001. T. 3. C. 618.

2 Теорія держави і права. Академічний курс: Підручник / За ред. О. В. Зайчука, Н. М. Оніщенко. К.: Юрінком Інтер, 2006. С. 38.

${ }^{3}$ Сливка С. С. Філософія права: методологічне осмислення / С. С. Сливка // Право України, 2011. N8. С. 62. 
through a set of legal concepts and categories, as well as the doctrine of theoretical foundations of their cognitive use ${ }^{4}$.

According to the scientific position of M.S. Kelman, methodology "is the doctrine of the structure, logical organization, methods, means and forms of activity of the researcher in the process of knowledge of the phenomena studied by him" .

Revealing the essence of the methodology of law, D.A. Kerimov pointed out, that "methodology, as a set of approaches, principles, methods ensuring the correct application of concepts and categories in cognition, should reflect the specifics of the process of cognition, orient the subject of cognition on how it is necessary to lead: what and in what sequence of procedures should be performed, which sides of the investigated sources of law should be studied, and from which one can abstract, how the theoretical and conceptual apparatus should be used in cognition, thus determining the most expeditious way of achieving objective truth",

The jurisprudence methodology can be consider from a narrow and wide angle viewpoint. When applying a broad approach, we can establish that methodology is not only a system of principles, approaches and methods, but also a system of knowledge about their purpose, and features of application. In turn, in a narrow sense, the methodology reflects the set of principles, approaches and methods used in the process of knowledge of state and legal phenomena.

In this research, the concept of methodology is considered in a narrow sense, and encompasses a system of principles, approaches, concepts, and methods used to define and substantiate the concept and legal nature of legal algorithms and technologies of legal practice.

\section{Postmodern principles of the research of legal algorithms}

An important step in determining the methodological foundations of the study, is the need to justify the type of legal thinking, that is in line with the spirit of the study, and is seen as the most successful for the disclosure of its subject.

Consideration the current tendencies of legal science, to seek an understanding of law, in our view, it is the integrative type of legal thinking,

\footnotetext{
${ }^{4}$ Скакун О. Ф. Теорія держави і права: Підручник / Пер. з рос. Харків: Консум, 2001. C. 8 .

5 Кельман М. С. Методологія сучасного правознавства: становлення та основні напрямки розвитку: дис.. ... д-ра юрид. наук: спец. 12.00.01. “Теорія та історія держави і права; історія політичних і правових учень” М. С. Кельман; МВС України, Львівський державний університет внутрішніх справ. Л., 2013. С. 44.

${ }^{6}$ Керимов Д. А. Методология права: Предмет. Функции. Проблемы философии права / Д. А. Керимов ; ИГиП РАН. [2-е изд.] М. : Аванта+, 2001. С. 70.
} 
that is such a "proper" way of research. Integrative understanding should be the necessary potential, for not only the disclosure of environmental rights, but also the establishment of action between "living law", "right in life", "right in texts". This type allows you to synthesize a legal idea and change rights, form rights, legal communication and relationships.

Also,It should be noted, that in the research, in the process of characterization of the type of legal understanding, the term "integrative legal thinking" is used and preferred, rather than the term "integrated legal understanding".

The indicated position is justified, on the based on etymology, a concept integration and integrity, where the first means a certain integration of the parts, as a whole through the synthesis of the starting provisions, and analysis of differences, and second, it reflects the inseparable connection of the parts, that form the whole.

In addition, the author's understanding and knowledge of the subject, the analysis of the initial provisions of the study were carried out, in accordance with the spirit of postmodern methodology of legal science.

It should be agreed with E.M. Oborotov, and M.I. Kozyubra, that "the attempt to introduce the principles of postmodern philosophy to legal studies with the understanding of pluralisticism, as the postulation of the multiplicity of worlds, the ontological diversity of the" beginnings "of the world have come to light and in the understanding of other legal basis of components juristic science, in particular, on the issue of legal understanding ${ }^{7}$. "From this situation, the type of legal thinking, based on the need to take into account the relativity of knowledge to the extra-scientific values, and orientations of the subject, begins to be defined, as determined by the outlook of the subject of cognition the image of law" .

In mentioned aspect, it is necessary to take into account E.M. Oborotov scientific position, related to the fact that, "the presence of a wide range of views on law (types of legal understanding), is recognized,as a direct and necessary consequence of the use of non-classical methodology, and methodology of postmodernism, which is characterized by the recognition of the" mosaic "of the existing legal world ... It is necessary, to develop an integrative understanding, within which for the association certain aspects of being right are subject to unification, thereby providing a synthesis of those constituents of law, that are denoted by different, competing scientific

\footnotetext{
${ }^{7}$ Оборотов Ю. Н. Філософія права і методологія юриспруденції / Ю.Н. Оборотов // Проблеми філософії права. 2003. Том 1. С. 41.

${ }^{8}$ Козюбра М. Праворозуміння : поняття, типи та рівень / М. Козюбра // Право Украйни : Юрид. журн. 2010. № 4. С. 14.
} 
theories. As a result of such integration, law should emerge as a multifaceted structure, and legal understanding, as a reflection of the axiomatic characteristics of legal reality"'.

In turn, P.M. Rabinovich stresses, that "the creation of an integrative theory of law must occur around a certain a single conceptual and meaningful nucleus, a certain outlook and philosophical core, should to be found, and the a priori postulation of the concept of law is thus declared inadmissible" 10 .

In some ways developing the approaches, proposed by E.M. Oborotov and P.M Rabinovich to integrative legal thinking, we can assume, that such an "conceptual and meaningful core" of the "mosaic of the existing legal world" is the axiological component of law. It is thanks to the unique values of law, and the identity of basic legal values, that we can define its social purpose, get closer to understanding its essence and nature.

It should be noted, that the idea of integrative jurisprudence,emerged around the 60s of the twentieth century in the United States. Jerome Hall and Harold Berman should be considered scholars, who substantiated the starting points, and the social value of this type of understanding the law. The main idea of integrative jurisprudence, they identified the possibility-necessity, in order to approximate the understanding of the nature of law, integration within the framework of a single legal theory, the initial postulates of value, normative and social existence of law. In particular, Jerome Hall noted, that law "is a type of social action, a process in which principles, values, and facts grow and become actualized" $"$.

N.M. Krestovskaya, analyzing the modern varieties of integrative (integral) legal understanding of the representatives of the post-Soviet space, notes that today it becomes possible to isolate: the realistic positivism of R.A. Romashov; communicative theory of law A.V. Polyakov; the dialogical theory of law I.L. Chestnova; the libertarian theory of V.S. Nersesianets, and the institutional theory of V.O. Chetvernin; the natural-positive theory of law V.M. Shafirov; social and naturalistic jurisprudence O.M. Kostenko; the demand theory of P.M. Rabinovich; value-normative theory of law E.M. Oborotov ${ }^{12}$.

9 Оборотов Ю. Праворозуміння як аксіоматичне начало (постулат) права / Ю. Оборотов // Право України 2010. № 4. С. 49-55.

10 Рабінович П. Трансформація методології вітчизняного праводержавознавства: досягнення і проблеми / П. Рабінович // Юридична Украӥна. 2003. № 1. С. 11.

${ }^{11}$ Hall J. Integrative Jurisprudence. N.Y,. 1961.

${ }^{12}$ Крестовська Н. М., Матвєєва Л. Г. Теорія держави і права. Підручник. Практикум. Тести: підручник / Н. М. Крестовська, Л. Г. Матвєєва. К.: Юрінком Інтер, 2015. C. $235-238$. 
Taking into account the opinion of A.M. Kovtonuk, that "the integrative type of legal thinking... called with the help of a new one to see nonclassical approach to scientific rationality, as a holistic intersubject phenomenon and not eclectic to combine, but synthesize a significant moments, developed by competing scientific theories" 13 , we can insist. that the distinctive types of integrative thinking do not contradict, but rather complement the universal perception and understanding of law, and therefore, they are perform necessary components in the process of learning about legal algorithms, and technologies of legal activity, within the framework basically, at least in the context of research, of an integrative type of legal thinking.

Given the insignificant difference in understanding between Western and post-Soviet scientific studies, regarding the starting points of the varieties of integrative legal comprehend, the latter served as the basis for forming a copyright understanding of the law and, accordingly, for constructing a further path of scientific development.

From the totality of these varieties of integrative legal thinking, the most important in the context of the study of legal algorithms and technologies of legal activity are: realistic R.A. Romashov positivism; communicative theory of law A.V. Polyakov; liberal theory of V.S. Nersesyanets; valuenormative theory of law E.M. Oborotov.

Analyzing E.M. Oborotov's substantiated value normative legal understanding, it should be noted that the right should be perceived, as a system in which, both norms and values function.

Value-normative understanding offers the right to understand "a historically formed, morally grounded and religiously validated, legalized value-normative system, which is designed for universal recognition (legitimating) and appropriate behavior of people, organizations, social communities, which uses procedures, formalized decisions and state coercion, to prevent and resolve conflicts, preserve social integrity" 14 .

The value-normative approach, first of all, allows to reveal axiological components of legal algorithms and technologies, to establish morally grounded, and religiously grounded principles of formation of procedures of behavior of people and other subjects of law.

As E.M. Oborotov emphasizes, "the central ideas of value-normative orthodoxy are, first, the conflicting purpose of law and, second, the need to

13 Ковтонюк А. М. Основні концепції права в інтегративній юриспруденції / А. М. Ковтонюк // Університетські наукові записки. 2007. № 4. С. 32.

14 Общетеоретическая юриспруденция. Учебный курс: учеб./ под ред. Ю. Н. Оборотова. Одесса : Феникс, 2011. С. 56-57. 
preserve existing social integrity. The semantic characteristics of law and the profession of lawyer are always associated with the possibility preventing conflict situations, and in their occurrence - the optimal solution. Just as the purpose of law from its inception in ancient society to the present day is to ensure the integrity of human existence from kind and tribe in antiquity, to family and state in modern life" $"$.

But, in this specified aspect, it is quite correct to note K.V. Gorobets, who states that "the concept of law developed within the framework of value, and normative understanding is relevant only, when law is understood,as a value and normative system of the national level, that is dependent on tradition., culture, religion, morality, etc. n. specific social community. It is difficult to argue, that modern international law, transnational law, integrative and global law, also identified as a systems of value-normative type, and therefore the definition given does not apply"16.

It should be noted, that value-based legal norms confirm the appropriateness of legal pluralism, justifying the need for coexistence, within the framework of the law of values and socially significant legal prescriptions.

Analyzing the concept of realistic positivism, we can distinguish the following components of the understanding of law: the universality and effectiveness of legal rules; the main purpose of legal influence is to ensure social stability, security and development; functional structure - legal norms whose social relations are governed by the rules of law, guarantees of implementation and results obtained through legal influence. Law, within the framework of this concept, is understood as "a set of formal sources"17.

The provisions, that have been substantiated within the concept of realistic positivism, make it possible to disclose the nature of the result of legal influence and, consequently, of the tasks to be formulated in the legal algorithm and of the rules, requirements and principles to be used in legal technologies.

From the point of view of communicative theory, law is a communicative order of relations based on socially recognized and binding norms, whose members have mutually agreed powers and responsibilities.

15 Общетеоретическая юриспруденция. Учебный курс : учеб./ под ред. Ю. Н. Оборотова. Одесса : Феникс, 2011. С. 57-58.

${ }^{16}$ Горобець К. В. Аксиосфера права: философский и юридический дискурс : моногр. $/$ К.В. Горобец. Одесса : Фенікс, 2013. С. 49.

${ }^{17}$ Ромашов Р. А. Реалистический позитивизм как интегративный тип современного правопонимания / Р. А. Ромашов // Університетські наукові записки НАУК-МА. 2007. № 4(24). C. 19. 
An important statement made in the framework of this theory is that law, as specific communication can exist without state, and state without law cannot exist. A.V. Polyakov, who is the author of the communicative theory of law, quite rightly states that "alongside state law there is a non-state law that has all the features of law, but at the same time, textual and functional features. Non-state law should include: corporate, sports, church and international law"18.

The communicative theory of law, not only reveals the essence of the relationship between the subjects, the order of implementation, which is reflected in legal algorithms, but also substantiates the need to use "nonstate law" in the process of regulating relations in society. Under analyze the provisions of the non-state (in our opinion, the term "soft law" is more apt), we can also establish the use of legal algorithms and technologies to ensure a proper way of communication and organization of legal activity.

A special place in the aspect of determining the methodological foundations of the study of legal algorithms, and technologies of legal activity is occupied by libertarian (libertarian-legal) theory of law developed by V.S. Nersesyanets. This theory very well substantiates the relationship, between the form and content of law, bringing as the central core of freedom, and formal equality.

V.S. Nersesyants defined the law, as "in accordance with the requirements of the principle of formal equality, a system of norms established or sanctioned by the state and secured by the possibility of state coercion. Law is a common and necessary form of human freedom, and freedom (its existence and realization) in social life is possible and valid only as a right and in the form of law"19.

There is no doubt that the obligatory condition for the implementation of quality legal activity is a formally expressed in the text legal act of a legal algorithms, which should not only be created in accordance with basic legal technologies, but also not contradict the ideas of justice, freedom, formal equality. Thus, the philosophical-theoretical constructs, proposed by V.S. Nersesyanets, make it possible to establish criteria for the relationship,between the "letter "and the "spirit" of socially significant prescriptions.

18 Поляков А. В. Общая теория права : курс лекций / А. В. Поляков. - СПб. : Юридический центр пресс, 2001. С. 327.

${ }^{19}$ Философия права: Учебник для вузов / В.С. Нерсесянц. 2-е изд., перераб. и доп. М.: Норма: НИЦ Инфра-М, 2013. С. 34. 


\section{Principles and methodological approaches to the research of legal algorithms}

Determined with the type of legal thinking, it is necessary to describe, those methodological constituents that was used in the process of research of legal algorithms, and technologies of realization of legal activity. In the marked aspect, the fully just is see realization of analysis of principles, approaches and methods, due to application of that it follows,to expose the characteristic signs of legal algorithms, and technologies of realization of legal activity, identify their place in legal reality.

The first basic principle, from which to begin research is the principle of historicism. Essence of legal algorithm and technologies of legal activity, it is possible to set on condition of consideration of features of his origin, forming and use in concrete historical condition and intercommunications. Systematized data in relation to historical genesis of legal algorithm, as historical phenomenon allow to represent all plenitude him social nature, to expose cause and effect connection of historical development of understanding of this meaningful instrument of formal expression of socially meaningful binding over's.

As marks H. M. Onishchenko, being base on principle of historical method, logical research of right exposes historical repetition, and general principles of their development. Therefore, any research of right in the basis, must be base on unity historical and logical. Logical determines the principles of approach to the historical, because it allows you to set the time of origin of law, to distinguish normative acts from customs, religious and moral norms ${ }^{20}$.

In turn, for establishment of features of intercommunication of legal algorithm and technologies of legal activity, with the system of the statelegal phenomena, it follows to apply principle of objectivity. Using this principle provides, not only a correct understanding of the nature of the relationship, between the subject and the object in the process of cognition, but also impartiality and deideologization of the research. The valued signs and descriptions of the investigated phenomenon, must be subject an analysis with the obligatory taking into account of achievements of civilization development of society. In addition, research objectivity, includes such elements as: modern society, legal reality, taking into account of that allows, to get to truth of presentation in relation to a role and place of legal algorithm in the system of adjusting of public relations.

\footnotetext{
${ }^{20}$ Оніщенко Н. М. Джерела права: теоретико-методологічні засади: дис...на здобуття наукового ступеня доктора юридичних наук за спеціальністю 12.00.01 - теорія та історія держави і права; історія політичних та правових учень / Наталія Миколаївна Оніщенко. Інститут держави і права ім. В. М. Корецького НАН України. Київ, 2009. С. 96.
} 
Taking into account modern progress of legal science, it's enriching trends to various knowledge, the special attention. it follows to spare principle of pluralism. The essence of this principle is revealed in the need, to apply various methods, concepts and approaches, in order to obtain a comprehensive understanding of the legal algorithm and technology of legal activity, their emergence, development and prospects. Than greater amount of criteria of analysis is used, the more reliable will be conclusions. It seems impossible, to generalize and formulate definition, on the basis of homogeneous indicators obtained from the research of the aspect of the phenomenon,under study from only one angle of view. It is necessary, to take into account,the maximal amount of existent looks to the problem, that is examined and to use totality of existent approaches, and methods with the aim of receipt complete, and balanced result.

Research principles form a certain base, on the basis of that general approaches, and concrete methods of realization of researches must be set forth taking into account the tendencies of modern legal science.

By a next element,that is to the constituents methodology of research has methodological approach. It should be noted, that in relation to determination of methodological approach,there is a certain discussion in modern jurisprudence.

A.F. Kryzhanovsky characterizes approaches, as "...foreshortening (in the wide understanding) of research vision, and thus, and the thoughts projections of object are certain cognitions that crystallize scientific strategy of understanding of right and legal phenomena, that is, the definition in general terms of the vector and the purpose of scientific research, as well as - its main stages and components"

By opinion of V.S. Bigun, methodological approach is a category more general for a method, and produced to the problem on the basis of certain theoretical theses, suppositions or concepts with the aim of search of optimal method of scientific search. At the same time, select a researcher approach determines the choice of concrete methods research and decision of problem $^{22}$.

Successful is determination, that is set forth A.O. Falkovsky, in accordance with that approach is the "form of organic combination of viewphilosophical orientation with a methodical tool, that is used in certain

\footnotetext{
${ }^{21}$ Крижановський А. Ф. Феноменологія правопорядку: поняття, виміри, типологія // Одес. нац. юрид. акад. О.: Фенікс, 2006. С. 23.

${ }^{22}$ Бігун В. С. Філософія правосуддя: ідея та здійснення: монографія / В. С. Бігун. К., 2011. C. 51.
} 
industry of research"23. From these positions essence of approach, does not close simple totality of methods (by methodology), but includes the components of the most general order, that is also included in bases of legal science.

Being based, on the marked principles in the process of establishment of essence legal algorithms, and technologies of legal activity, it follows to use various methodological approaches in particular: ideal-realistic, hermeneutics, valued, active, system and anthropological.

The ideal-realist approach is based on a complementary and holistic concept of knowledge of law, which in turn synthesizes ideas (metaphysics), facts (positivism) and appraisals (axiology) and is an attempt to understand the true combination of these most important legal spheres.

According to opinion V.V. Dudchenko, "in the methodology of idealrealistic synthesis, the confrontation between metaphysics and positivism is overcome, which allows one to know legal reality without its dogmatization, in its entirety. This approach leads us to the idea of a "normative fact". It is in this idea that the complexity of law finds its culminating point, and the phenomenon of law itself becomes accessible to understanding. At the same time, by solving the problem of "normative facts", it is possible to solve most of the urgent problems of modern law theory (problems of sources of law and definition of law according to its source, antinomies in the sphere of law, the role of organization and coercion, problems of correlation of public and private law, social law, legal pluralism, etc.). "On the basis of the above, the scientist formulates the ideal-realist concept of law as "a system, an order of imperative-attributive norms that acquire legitimacy, effectiveness and social guarantee of efficiency through normative facts" 24 .

Application of the ideal-realistic approach allows to reveal not only the view-ideological factors of the evolution of law, but also to determine the significance of its forms, features of their creation and implementation.

The hermeneutical approach is based on a set of principles and methods of interpretation and interpretation of legal texts,that can take the form of both legal and legal documents, and research of scientific works of scientists is equally important. Within the framework of hermeneutics approach possibility of opening features co-operation of subjects public relations is

${ }^{23}$ Фальковський А. О. Аксіологічний підхід в методології сучасної юриспруденції : автореф. дис. на здобуття наук. ступеня канд. юрид. наук.: спец. 12.00.12. "Філософія права" / А. О. Фальковський Нац. ун-т. Одес. юрид. акад. О., 2011. С. 7.

${ }^{24}$ Дудченко В. В. Традиція правового плюралізму: західна та східна інтерпретація : автореф. дис. ... д-ра юрид. наук: 12.00.01/ В. В. Дудченко; наук.консультант Ю. М. Оборотов; Нац. ун.-т “Одеська юридична академія”. Одеса, 2007. С. 5. 
created on the occasion not only creation of legal algorithm but also order of his realization.

Such model answers the task of the legal adjusting and allows to expose the elements of social nature of the investigated phenomenon.

On this occasion V. Dudchenko, specifies that, the "article of hermeneutics of right embraces interpretation of concept right, basic legal concepts, norms of right and legal facts with the aim of finding out of their sense" 25 .

The valued approach,allows to expose the certain system of values, due to the analysis of, that becomes possible a location and role of legal algorithm in legal reality. The valued analysis of legal algorithm must be based,on taking into account of such general social necessities and interests as: social justice, freedom, duty, orderliness, formal definiteness, state security and other. The use of the valued approach,allows to give the estimation of efficiency of legal algorithm, set his setting in regulation of public relation.

Active approach, in opinion of S.D. Gusarev, it is "harmonious totality of options, receptions, ensemble of methods, among that the method of activity is considered leading, and other in relation to him carry out an attendant role. This approach, allows to pay attention researcher,not only on a problem own to activity, but also on other phenomena, in correlation or co-operating with that there is activity. The aspects of including concrete type of activity are studied to the system of higher level, or taking of her to the certain type of social activity,and others like that, (social value, conditionality by development of public relations status, functional setting of activity or function of subject of activity, intercommunication of the functional setting and structure, description of the state, determination of criteria of efficiency, prospect of development, interaction)" ${ }^{\text {26 }}$.

Active approach, it follows to apply at correlating, between legal algorithms and legal activity, determination and application of technologies of their creation and realization.

The system approach, allows to conduct the all-round analysis of component parts of unit,that are in organic unity and co-operation. The system is constructed,as the organized orderliness of elements is based on their mutual ligaments and co-operation. At the use to methodology of the systematic approach static, structural, dynamic components and properties are investigated, them internal and external displays, genetic and functional

25 Дудченко В. В. Герменевтика права: розвиток юриспруденції : навч. посіб./ В. В. Дудченко, М. Р. Аракелян, В. В. Завальнюк. Одеса : Фенікс, 2014. С. 55.

${ }^{26}$ Гусарев С. Д. Юридична діяльність: методологічні та теоретичні аспекти : дис. ... д-ра юрид. наук: 12.00.01 / Київський національний ун-т внутрішніх справ. К., 2007. C. 64-65. 
ligaments, features of co-operating with external an environment. The system approach in investigational legal algorithm, allows to define him underlying structure, mechanism and features of action of his separate components as inter se so in co-operating with other constituents of legal reality (by a legal norm, by legal acts and other).

Anthropological approach in methodology of research technologies and algorithms legal activity is used as one of system-forming. Anthropology understands, as science about an origin and evolution of man. What touches legal anthropology, that is named yet anthropology of right, then she studies the processes of jurisdictions of human existence, predefined by the concrete historical types of civilizations. As a result, patterns are revealed that explain the main points associated with the legal life of mankind. Legal anthropology in its research is based,on the analysis of oral and written monuments of law, on the one hand, and the practice of public life, on the other.

So, according to opinion B.C. Nersesyantsa, "legal anthropology is the science of human as a social essence in its legal manifestations, measurements, characteristics. It studies the legal forms of social life of people from ancient times to this day. In its subject area includes legal systems, and in general - the whole complex of legal phenomena (all legal forms in the broadest sense of the word - legal rules, relationships, ideas and ideas, institutions, procedures, ways of regulating behavior, protecting order, solving conflicts, etc.), that are formed in different communities (primitive, traditional, modern), in different ethnic groups (peoples, nations), in different epochs and in different regions of the world. This provision is of fundamental importance in the study of legal systems, legal traditions and their diversity",27.

According to opinion V.V. Zavalnyuk, "the anthropological approach to research of human, culture and society is viewed from the point of view of the basic directions of anthropological knowledge - physical, philosophical, social and cultural anthropology, or simply from the point of view of the human dimension of the researched phenomena. The anthropological approach to human research in this context is related to the research point of view. In the content of the anthropological approach, includes the choice of object and subject, methodology and methods of cognition of man, culture and society. Anthropological approach is useful to overcoming of

${ }^{27}$ Нерсесянц В. С. Юридическая антропология как наука и учебная дисциплина : [предисловие] // Рулан Н. Юридическая антропология. Учебник для вузов // Перевод с франц. Ответственный редактор - академик РАН, доктор юридических наук, профессор. В. С. Нерсесянц. М.: Издательство НОРМА, 2000. С. 2. 
ethnocentric view to social development of man and societies, his use it is necessary pre-condition of adjusting of connections between with civilizations, legal systems, states and people that present different legal cultures. Anthropological knowledge are a considerable value for the modern mechanism of action of right, as anthropology comes forward as a certain kernel of rationalization and ideologization of culture. Legal anthropology is the product of activity of man, as gives possibility to learn public processes are certain and to influence on them, and also to use her potential in forming of legal reality ${ }^{28}$.

Fully correctly, V. N. Shapoval marks, that a "human is not a object, but subject of social actions, that through her and for her there are all surrounding transformations, that she is a not mechanism and not factor, but creature that has a mind and free will, then such position will be more friendly to understanding of sense of right, improvement of man and society ${ }^{29}$.

It is impossible to consider a right separately from a man, in fact essence the right is indissolubly related to fundamental principles of human life and cohabitation $^{30}$.

In the marked aspect, it follows to agree with the position of T.O. Podkovenko, that grounds, that "the existence of man in the world of law - here that comes forward as a reliable index of a civilized of any legal system $^{31}$.

Practical application of anthropological approach predetermines realization, based on humanistic principles, anthropological interpretation of legal norms. That in turn brings us over to opening of paradigms of legal anthropology, to which should be attributed: paradigm of man as to the center of right and criterion of the social normative regulation, paradigm of legal development, paradigm of structural functionality of legal environment of $\operatorname{man}^{32}$.

\section{The outcoming methods of research of legal algorithms}

Taking into account position and grounds set forth in principles and approaches becomes possible to define totality of methods due to application

28 Завальнюк В. В. Роль юридичної антропології у сучасному правовому розвитку /

В. В. Завальнюк // Актуальні проблеми держави і права. 2009. Вип. 47. С. 311.

29 Шаповал В. Н. Антропологічні виміри розвитку філософії права в Україні / В. Н. Шаповал // Проблеми філософії права. 2003. Т. 1. С. 130.

${ }^{30}$ Антропологія права: навч. Посіб. / В. І. Кушерець, В. М. Кравець, С. О. Мосьондз [та ін.]; за ред. В. І. Кушерця. К.: Знання України, 2011. С. 5.

${ }^{31}$ Подковенко, Т. О. Антропологічний підхід до права як основа юридичної науки [Електронний ресурс] / Т. О. Подковенко // Право і суспільство. 2015. № 2. С. 34.

${ }^{32}$ Пучков О. А. Юридическая антропология и развитие науки о государстве и праве:

Теоретические основі: диссертация ... доктора юридических наук: 12.00 .01 Екатеринбург, 2001. С. 64. 
of that opens up nature of legal algorithm. M.S. Kelman notes, that a method is the most wide, general approach to the study of that or other the and natural, and public phenomenon with application of that it is possible to score a success with every area of science. Methodological culture of lawyers it him world view maturity, sociological literacy, legal being informed and professional mastery ${ }^{33}$.

Being base on the declared principles and approaches in the process of opening of essence and social nature of legal algorithm and technologies of legal activity, it follows to use the next groups of methods : general methods of cognition; general-scientific methods; interdisciplinary methods ${ }^{34}$; specially-scientific methods of legal sciences.

From totality of general methods of cognition it follows to use: method of description for describe of legal algorithm by a reflection in a certain, in common understanding sign system, information regarding its nature and form; a method of comparison to establish the identity or distinction, between a legal algorithm and concepts such as: principle of law, legal act, model of behavior, formal expression of prescriptions, etc.; a method of generalization is for determination of general concept of legal algorithm with taking into account of all his properties and signs.

From the totality of general-scientific methods of cognition the special attention, it follows to the spare to the dialectical method, that predetermines objective, all-round, and concrete consideration of the legal algorithm with taking into account the inherent to him ties and exposure of interdependence of form and essence.

It follows to take into account that plenitude of scientific research legal algorithms and technologies of legal activity, related also to the use on all stages of such general-scientific methods as: analysis, synthesis, abstracting, generalization, induction, analogy.

From totality of interdisciplinary methods it follows to use: sociological method at establishment of concrete social facts and requirements of creation of legal algorithms; statistical method for quantitative description of cases of the use of legal algorithms in dispositions of principals of law in the legal system of Ukraine; concretely-historical at the studied specifics of origin, development and features of the use of legal algorithms at the social regulation.

${ }^{33}$ Кельман М. С, Мурашин О. Г. Загальна теорія держави і права: Підручник. К.: Кондор, 2006. С. 663.

${ }^{34}$ Крестовська Н. М., Матвєєва Л. Г. Теорія держави і права. Підручник. Практикум. Тести: підручник / Н. М. Крестовська, Л. Г. Матвєєва. К.: Юрінком Інтер, 2015. С. 30. 
Next to this, in research it is necessary to use the specially-scientific methods of legal sciences : hermeneutics method - for research of features of understanding and interpretation of legal algorithm in different historical periods, and with taking into account of approaches of different schools understanding of right; formally-dogmatic method - at the analysis of positions of legal facts and legal texts in relation to establishment of normative model of legal algorithm and order of his reflection in legal acts; comparatively-legal - for comparison of legal concepts, phenomena and processes, in relation to fixing of legal algorithms in legal acts that exist simultaneously in different countries, the analysis of features of organization and realization of legal activity.

\section{CONCLUSIONS}

In summary, it should be emphasized, that certain methodological tools are used to establish the order of creation of quality legal algorithms in accordance with existing legal technologies, requirements of society and provisions of legislation.

By opinion E. M. Oborotov, "Question of filling of methodology of jurisprudence by conceptual ideas, principles, approaches, methods, receptions, building connections the conceptual and instrumental level, "the statement of features methodology of the research activity is in the sphere of right and state,- it all presents the actual task of new correction to the complex of methodological problems, with moving towards a modern vision of methodology of jurisprudence",35.

\section{SUMMARY}

The noted type of legal thinking, principles, approaches and methods of scientific knowledge, reflect outcoming methodological principles of the research of algorithms and technologies of legal activity in modern law, and create the basis for obtaining comprehensive and complete information about their legal nature and social purpose.

\section{REFERENCES}

1. Антропологія права: навч. Посіб. / В. І. Кушерець, В. М. Кравець, С. О. Мосьондз [та ін.]; за ред. В. І. Кушерця. К.: Знання України, 2011. $223 \mathrm{c}$.

35 Методологія та інноватика загальнотеоретичної юриспруденції : монографія / [Ю. М. Оборотов, А. П. Овчиннікова, В.В.Завальнюк та ін.]; за ред. Ю. М. Оборотова.Одеса: Фенікс, 2019. С. 8 . 
2. Бігун В. С. Філософія правосуддя: ідея та здійснення: монографія / В. С. Бігун. К., 2011. 303 с.

3. Горобець К. В. Аксиосфера права: философский и юридический дискурс : моногр. / К.В. Горобец. Одесса : Фенікс, 2013. 218 с.

4. Гусарев С. Д. Юридична діяльність: методологічні та теоретичні аспекти : дис. ... д-ра юрид. наук: 12.00.01 / Київський національний унт внутрішніх справ. К., 2007. 422 с.

5. Дудченко В. В. Герменевтика права: розвиток юриспруденції : навч. посіб. / В. В. Дудченко, М. Р. Аракелян, В. В. Завальнюк. Одеса : Фенікс, 2014. 184 с.

6. Дудченко В. В. Традиція правового плюралізму: західна та східна інтерпретація : автореф. дис. ... д-ра юрид. наук : 12.00.01 / В. В. Дудченко; наук.консультант Ю. М. Оборотов; Нац. ун.-т “Одеська юридична академія". Одеса, 2007. 35 с.

7. Завальнюк В. В. Роль юридичної антропології у сучасному правовому розвитку / В. В. Завальнюк // Актуальні проблеми держави і права. 2009. Вип. 47. С. 309-312.

8. Кельман М. С, Мурашин О. Г. Загальна теорія держави і права: Підручник. К.: Кондор, 2006. 477 с.

9. Кельман М. С. Методологія сучасного правознавства: становлення та основні напрями розвитку : автореф. дис. докт. юрид. наук : 12.00.01 / М. С. Кельман. К., 2013. 42 с.

10. Керимов Д. А. Методология права: Предмет. Функции. Проблемы философии права / Д. А. Керимов ; ИГиП РАН. [2-е изд.]. М. : Аванта+, 2001. 559 с.

11. Ковтонюк А. М. Основні концепції права в інтегративній юриспруденції / А. М. Ковтонюк // Університетські наукові записки. 2007. № 4. C. 32-37.

12. Козюбра М. Праворозуміння : поняття, типи та рівень / М. Козюбра // Право України : Юрид. журн. 2010. № 4. С. 10-21.

13. Крестовська Н. М., Матвєєва Л. Г. Теорія держави і права. Підручник. Практикум. Тести: підручник / Н. М. Крестовська, Л. Г. Матвєєва. К.: Юрінком Інтер, 2015. 584 с.

14. Крижановський А. Ф. Феноменологія правопорядку: поняття, виміри, типологія // Одес. нац. юрид. акад. О.: Фенікс, 2006. 196 с.

15. Методологія та інноватика загальнотеоретичної юриспруденції : монографія / [Ю. М. Оборотов, А. П. Овчиннікова, В. В. Завальнюк та ін.]; за ред. Ю. М. Оборотова. Одеса: Фенікс, 2019. 420 с.

16. Нерсесянц В. С. Юридическая антропология как наука и учебная дисциплина : [предисловие] // Рулан Н. Юридическая антропология. Учебник для вузов // Перевод с франц. Ответственный редактор - 
академик РАН, доктор юридических наук, профессор. В. С. Нерсесянц. М.: Издательство НОРМА, 2000. 310 с.

17. Оборотов Ю. Праворозуміння як аксіоматичне начало (постулат) права / Ю. Оборотов // Право України. 2010. № 4. С. 49-55.

18. Оборотов Ю.Н. Філософія права і методологія юриспруденції / Ю.Н. Оборотов // Проблеми філософії права. 2003. Том 1. С. 41-43.

19. Общетеоретическая юриспруденция. Учебный курс : учеб. / под ред. Ю. Н. Оборотова. Одесса : Феникс, 2011. 436 с.

20. Оніщенко Н. М. Джерела права: теоретико-методологічні засади: дис...на здобуття наукового ступеня доктора юридичних наук за спеціальністю 12.00 .01 - теорія та історія держави і права; історія політичних та правових учень / Наталія Миколаївна Оніщенко. Інститут держави і права ім.. В. М. Корецького НАН України. Київ, 2009. $396 \mathrm{c}$.

21. Подковенко, Т. О. Антропологічний підхід до права як основа юридичної науки / Т. О. Подковенко // Право і суспільство. 2015. № 2. C. 32-38.

22. Поляков А. В. Общая теория права : курс лекций / А. В. Поляков. СПб. : Юридический центр пресс, 2001. 642 с.

23. Пучков О. А. Юридическая антропология и развитие науки о государстве и праве: Теоретические основы: диссертация ... доктора юридических наук: 12.00.01 Екатеринбург, 2001. 503 с.

24. Рабінович П. М. Методологія юридичної науки // Юридична енциклопедія. К., 2001. Т. 3. С. 618-627.

25. Рабінович П. Трансформація методології вітчизняного праводержавознавства: досягнення і проблеми / П. Рабінович // Юридична Україна . 2003. № 1. С. 10-18.

26. Ромашов Р. А. Реалистический позитивизм как интегративный тип современного правопонимания / Р. А. Ромашов // Університетські наукові записки НАУК-МА. 2007. № 4(24). С. 13-20.

27. Скакун О.Ф. Теорія держави і права: Підручник / Пер. 3 рос.Харків: Консум, 2001. 656 с.

28. Сливка С. С. Філософія права: методологічне осмислення / С. С. Сливка // Право України, 2011. N8. С. 61-70.

29. Теорія держави і права. Академічний курс: Підручник / За ред. О. В. Зайчука, Н. М. Оніщенко. К.: Юрінком Інтер, 2006. 688 с.

30. Фальковський А. О. Аксіологічний підхід в методології сучасної юриспруденції : автореф. дис. ... канд. юрид. наук : 12.00 .12 / А. О. Фальковський; кер. роботи Т. В. Розова; Нац. ун.-т “Одеська юридична академія". Одеса, 2011. 17 с. 
31. Философия права: Учебник для вузов / В.С. Нерсесянц. 2-е изд., перераб. и доп. М.: Норма: НИЦ Инфра-М, 2013. 848 с.

32. Шаповал В. Н. Антропологічні виміри розвитку філософії права в Україні / В. Н. Шаповал // Проблеми філософії права. 2003. Том 1. C. $129-130$.

33. Hall J. Integrative Jurisprudence. N.Y,. 1961. URL: https://www.repository.law.indiana.edu/cgi/viewcontent.cgi?article=2459\&c ontext=facpub

\section{Information about the author:} Manko D. G., Candidate of Juridical Sciences, Associate Professor at the Department of State and Law Disciplines, International Humanitarian University 33, Fontanska Road str., Odessa, 65009, Ukraine 